\title{
Potato Landraces and Their Wild Relatives in 3 Micro-centers of Diversity in Ecuador: Farmers' Perception and Ecogeography
}

\section{Álvaro Ricardo Monteros-Altamirano ( $\nabla$ alvaro.monteros@iniap.gob.ec )}

Instituto Nacional Autónomo de Investigaciones Agropecuarias: Instituto Nacional Autonomo de Investigaciones Agropecuarias https://orcid.org/0000-0002-1271-3513

\section{A. Monteros-Altamirano}

Instituto Nacional de Investigaciones Agropecuarias, Ecuador

\section{F. Yumisaca-Jiménez}

INIAP: Instituto Nacional Autonomo de Investigaciones Agropecuarias

\section{R. Aucancela}

INIAP: Instituto Nacional Autonomo de Investigaciones Agropecuarias

\section{J. Coronel}

INIAP: Instituto Nacional Autonomo de Investigaciones Agropecuarias

\section{Corozo-Quiñonez}

Universidad Técnica de Manabí: Universidad Tecnica de Manabi

\section{K. Cunguán}

Universidad Técnica del Norte: Universidad Tecnica del Norte

\section{Research Article}

Keywords: traditional knowledge, genetic diversity crossing, gene flow

Posted Date: May 10th, 2021

DOI: https://doi.org/10.21203/rs.3.rs-473441/v1

License: (c) (1) This work is licensed under a Creative Commons Attribution 4.0 International License. Read Full License

Version of Record: A version of this preprint was published at Genetic Resources and Crop Evolution on November 10th, 2021. See the published version at https://doi.org/10.1007/s10722-021-01285-3. 


\section{Abstract}

Ecuador is one of the centers of diversity for wild and cultivated potatoes. Three micro-centers of diversity were previously identified based on germplasm collecting passport data of potato landraces and their wild relatives. The objective of this study was to understand the potential hybridization dynamic of the genetic diversity present in situ in these micro-centers (provinces of Carchi, Chimborazo and Loja in Ecuador) by means of: 1 . Reviewing the possibility of an eventual genetic cross within intercropped potato landraces through surveys to local producers; 2 . Reviewing the possibility of potato landraces crossing with their wild relatives, also according to local producers; and 3. Map the actual geographic location of recent collections of potato landrace and wild potato relatives in the study areas. Information from farmers and eco-geographic data demonstrated that there is no potential crossing between wild and cultivated potato species. Probably the existing genetic variability in Ecuador has been accumulated since the historical movement of potato landraces by American ancestors from the center of origin in Peru and Bolivia and the continuum knowledge and seed sharing besides the conscious and unconscious selection of potato landraces by local farmers for centuries. Additionally, we discuss options to conserve both cultivated and wild potato species in Ecuador due to apparent current genetic erosion processes.

\section{Introduction}

At the beginning of the 20th century, the Russian scientist Nikolai I. Vavilov claimed that crop variation was correlated with global geographic distributions (Vavilov, 1927). The Andean region was identified as one of the centers of origin and domestication of various crops, including potatoes. Potato was first domesticated in central South America around Lake Titicaca 10,000 to 6,000 years ago (Brush et al., 1995; CIP, 2020; Hawkes, 1988; Ames et al., 2008). Ecuador up North is one of the centers of diversity for cultivated and wild potatoes (Hawkes, 1988; Hawkes, 1990; Monteros-Altamirano, 2011). The Ecuadorian potato diversity includes three taxa of cultivated tuber-bearing potatoes, known as Solanum tuberosum L. Andigenum group, diploid, triploid and tetraploid, previously classified as (Solanum phureja, S. chaucha and S. tuberosum subsp. Andigena) added to 23 wild species related to potato (Spooner et al., 1992; Spooner et al., 2007; Spooner et al., 2014). Recently Naranjo et al. (2020) collected 8 wild potato-related species in the Ecuadorian highlands: Solanum albicans (Ochoa) Ochoa, Solanum albornozii Correll, Solanum andreanum Baker, Solanum chilliasense Ochoa, Solanum chomatophilum Bitter, Solanum colombianum Dunal, Solanum minutifoliolum Correll and Solanum olmosense Ochoa.

In Ecuador, agriculture began in the so-called "formative period" (Huerta, 1966; Reyes, 1984). This period lasted from 4,400 to $300 \mathrm{BC}$ and saw the beginning of sedentary village life, agriculture and pottery (Zeidler, 2008). The first archaeological record of potatoes in Ecuador was found in Cotocollao (Pichincha province, northern Ecuador) dating from 1500 BC (Zeidler, 2008). When the Spanish arrived in South America at the end of the 15th century, they discovered what for them were new plant species. Cieza de León was one of the first Europeans to mention the potato in 1553, both in Quito, Ecuador, where he first saw the plant cultivated, and in the highlands of Peru (cited in Hawkes, 1947). Native potatoes grown in the Andes have been described under different names: Indian Potatoes (Hawkes, 1947), varieties of 
native potatoes (Brush et al., 1981), potatoes grown in the Andes (Quiros et al., 1990); native potato cultivars (Zimmerer, 1991), local potato varieties (Brush et al., 1994) or cultivars (De Haan, 2009). The native potatoes growing in the Andes have been described under different names, e.g. Indian potatoes (Hawkes, 1947), native potato varieties (Brush et al., 1981), Andean cultivated potatoes (Quiros et al., 1990); native potato cultivars (Zimmerer, 1991), potato landraces (Brush et al., 1994) or cultivars (De Haan, 2009).

Data from collections of cultivated and wild potatoes in Ecuador, carried out in the 1970's and 1980's (Database of the International Potato Center, CIP), served to identify 3 micro-centers of genetic diversity by the North, Central and South of the country Monteros-Altamirano $(2011 ; 2018)$. These 3 micro-centers (provinces of Carchi, Chimborazo and Loja respectively) were chosen, since a high number of cultivated potatoes and their wild relatives coexist. Monteros-Altamirano et al. (2018), studied recently collected local diploid, triploid and tetraploid potato landraces from these three microcenters and found high allelic diversity based on SSR (Simple Sequence Repeat) information; for tetraploid landraces this diversity was comparable to the variation found in a European collection of 892 varieties (Reid et al., 2011; MonterosAltamirano, 2017). The presence of unique alleles in local Ecuadorian landraces showed that there is untapped variation, as previously reported for Peruvian potatoes by Quiros et al. (1990) and De Haan (2009). Crop genetic resources are known to be the result of collective actions over many generations of farmers and is the result of shared knowledge, seed sharing, and accumulation of valuable traits (selection) in crop populations (Jarvis and Hodkin, 1999; Brush, 2007). Farmers decide how to manage crop populations in their fields, which can have an effect on existing genetic diversity; if farmers are aware of hybridization, they could promote or avoid the process between landraces or gene flow with wild relatives (Jarvis et al., 2000).

In conventional production systems in Ecuador, potatoes are vegetative propagated by means of "tuberseeds", however, true potato seeds (TPS) are the genuine sexual botanical seeds of the potato (Cuesta et al., 2002). These seeds are contained in fruits (berries) of approximately $2-3 \mathrm{~cm}$ in diameter that grow from inflorescence; individual sexual potato seeds measure between 1.2 and $2.8 \mathrm{~mm}$ and weigh on average 50-100 mg per 100 seeds that may even present dormancy (FAO, 1991; Struik and Wiersema, 1999; Upadhya and Cabello, 2000; Monteros, 2002). In this way, TPS have been generated from cultivated potatoes, landraces and wild relatives to be conserved in genebanks (FAO, 1998; CIP, 2000; Naranjo et al., 2020).

By using the same 3 micro-centers of potato diversity identified for Ecuador by Monteros-Altamirano (2018), the objective of this study was to understand the potential hybridization dynamic of the genetic diversity present in situ by means of: 1 . Reviewing the possibility of an eventual genetic cross within intercropped potato landraces through surveys to local producers; 2 . Reviewing the possibility of potato landraces crossing with their wild relatives, also according to local producers; and 3. Map the actual geographic location of recent collections of potato landrace and wild potato relatives in the study areas.

\section{Materials And Methods}




\section{Study sites}

The study locations were the provinces of Carchi, Chimborazo and Loja; these provinces correspond to the three micro-centers of diversity of cultivated and wild potatoes previously identified by MonterosAltamirano (2018) for Ecuador.

\section{Survey}

First, the consent of the farmers was sought previously to carry out with the interviews. With this, 8 questions were asked to understand the potential hybridization dynamic of the genetic diversity present in situ at the microcenters.

Questions A and B tried to answer if there is a possible natural hybridization between local landraces: A. Do you grow potato landraces mixed or separated in rows? B. Do you think that if you plant the potatoes together they will cross? To identify if farmers use the berries of potato plants in a potential natural hybridization, we asked the following question: C. Do you collect potato fruits in the field? To ascertain whether the farmers are aware of the existence of wild potatoes, the following question was asked: D. List the common names of the wild potatoes that you know. After we verified that the farmers know about wild potatoes, it was asked: E. Have you seen wild potatoes near the field where you grow your potato landraces? Later, we inquire about their perception of whether they see a potential cross between the wild relatives and their potato landraces with the following question: F. Do you think that wild potatoes can cross with cultivated potatoes? To inquire a little more about farmers' knowledge about wild potatoes, we asked about their use: G. Do you know what wild potatoes are used for? Finally, to check if there is another potential source of diversity in the potato fields, the following question was asked: H. Do you exchange potato seed with your neighbors? Finally, the data gathered from these questions were categorized and ordered in a Microsoft Excel ${ }^{\circledR}$ matrix and then analyzed in SPSS to determine frequencies of the responses (IBM Corp., 2011).

\section{Interviewees description}

The interviewees were farmers who still grow potato landraces at each of the 3 identified micro-centers, there were 50 representative farmers per micro-center (province) according to Monteros-Altamirano (2011, 2018). Most of the farmers growing potato landraces in the 3 studied areas were over 50 years old, with an average age of 53 years old. The racial distribution (mestizo and indigenous) differed between the provinces, being $100 \%$ mestizo in Carchi; $20 \%$ mestizo and $80 \%$ indigenous in Chimborazo; and $70 \%$ mestizo and $30 \%$ indigenous in Loja. Native potato growers are mainly farmers with properties of less than 3 ha (48\% farmers in Carchi, 76\% in Chimborazo and 62\% in Loja). The respondents mainly have a high school education level: $90 \%$ in Carchi, $94 \%$ Chimborazo and $84 \%$ in Loja.

\section{Potato flowering assessment}

The potato landraces collected in Carchi (25 accessions), Chimborazo (43) and Loja (30), were planted at the Santa Catalina Experimental Station of the National Institute for Agricultural Research (INIAP) in 
Quito (altitude 3,050 masl, latitude $0^{\circ} 22^{\prime} 8^{\prime \prime} \mathrm{S}$ and longitude $78^{\circ} 33^{\prime} 24^{\prime \prime} \mathrm{W}$ ). Data recorded the number of days from sowing until when the accession presented $50 \%$ of flowering. Data was analyzed in Infostat (2008).

\section{Geographical location of native potatoes in relation to their wild species}

Although the micro-centers (provinces) were identified in the first instance by using available passport data (locality, latitude and longitude,) from Ecuadorian potato collections by CIP and INIAP of the 1970's and 1980's (Monteros-Altamirano, 2011), for this study, passport data from more recent collections of native potatoes (98 accessions: 25 Carchi, 43 Chimborazo and 30 Loja) and wild relatives (30 accessions: 4 Carchi, 10 Chimborazo and 16 from Loja) was used (Monteros-Altamirano, 2011, 2018; Naranjo et al., 2020). These passport data generated graphs of collection points by provinces in the arcGIS program (ESRI, 2011). It is important to mention, that during the collections of potato landraces, if any wild plant potato-like were sighted in a perimeter of $500 \mathrm{~m}$ of the farmers' plots, herbarium samples were prepared to identify them with experts.

\section{Results}

Figure 1 includes several histograms with frequencies for the responses to 6 of the 8 questions about farmers' perception on their cultivated and wild potatoes.

\section{About whether farmers grow varieties together or separately}

When asking farmers if they plant their potato varieties together or separate in rows in the field (Figure 1A), farmers from Carchi, Chimborazo and Loja answered that they mostly plant potato landraces separately (98\% in Carchi and Chimborazo; and 92\% in Loja). Only one farmer in Carchi, another in Chimborazo and 4 in Loja plant the native potato varieties intermixed within the same row.

\section{About whether native potato varieties are crossed when planted together}

Based on figure 1B, we can observe that most of the farmers in the 3 provinces do not think that potato landraces cross if they are planted nearby (Carchi 59\%, Chimborazo 66\% and Loja 76\%). Farmers who think that landraces cross are: $16 \%$ from Carchi, $20 \%$ from Chimborazo and $18 \%$ from Loja. A lower percentage (except Carchi with $24 \%$ ) think that perhaps potato landraces could cross, but they have not seen it, so the answer was they do not know. Some farmers explained a bit more about their answers and we can summarize them by province: in Carchi four farmers ( 3 men and a woman) think that landraces do interbreed because at harvest they find potatoes that change colors. On the other hand, two other male farmers think that cultivated potatoes do change, but not because they cross, but because they degenerate and change. In Chimborazo, 5 women farmers think that "landraces do interbreed, because if they plant mixed varieties, the product comes out mixed". Another mentioned that potato landrace Uchurumi changes to Cuchisele (which is a potato that grows as a weed on corn). Another farmer mentioned that potatoes do grow when the fruits "papa lulü" fall; while another farmer mentioned that 
fruits fall, and plants grow from the seeds. Only one farmer mentioned that they do breed because landraces "get married." In Loja, two male and six female farmers thought that potatoes do not mixed because "each plant is different, independent and they produce separately."

\section{About the collection of potato fruits (sexual seeds) in the field}

Figure $1 \mathrm{C}$ shows that the majority of farmers in the province of Carchi, Chimborazo and Loja do not collect potato fruits 74,72 and $84 \%$ respectively, only few of them collect them (24, 22 and $16 \%)$. A low percentage 2, 6 and $0 \%$ of farmers per province, claimed did not know. In Carchi, 9 male farmers and one female mentioned that the plants are born from the tzimbalos (fruits) naturally and they mention occurring in the following landraces: Violeta, Mampuera, Curipamba, Leona, Rosa, Curipamba, Ojona, Pamba Rosa, Pamba blanca and some Chauchas (S. tuberosum, diploids). Two farmers mentioned that the fruits do not ripen or that they rot. In this province, two farmers mentioned that they have knowledge of seedlings coming out of potato sexual seeds since a well-known Ecuadorian breeder from the province (Mr. G. Bastidas) created a famous local variety called "SuperChola" using this scheme. In Chimborazo, the fruit of the potato is called "pulo" or "papa lulü". One farmer noticed that fruit production has decreased in her potatoes. A male and a female farmer mentioned that fruits are "harvested" but no tests have been done to see if they germinate. Two women and a man mentioned that the "fruits are eaten fresh." There are 3 farmers who have done germination tests and they know that seedlings do come out, one says: "I have tested and they came out well"; another says that: "seedlings come out almost the same as the original", also mentioning that she has done the test in an improved variety "Gabriela" but not with the natives; while another mentioned that only rickety plants grow out but they are not used. Two others mentioned that "pulo" is not used in anything, it falls and rots, although they mentioned that they have heard that potatoes come out, but they have not done the test. In Loja farmers mentioned that the fruits are called "tzimbailos", 11 farmers ( 5 men and 6 women) mentioned that they only fall and rot. Eight farmers ( 3 women and 5 men) mentioned that these are consumed especially by children since they "suck fruits". Seven farmers ( 3 women and 4 men) mentioned that they do nothing with the fruits, that some fall or they are cut out during crop development, but they do not produce potatoes; fruits are collected, but not sown. Finally, one farmer mentioned that potato fruits are used to feed animals.

\section{About the knowledge on wild potatoes.}

In Carchi, farmers (44\%) indicate that wild potato species take the name of "papa de la vieja" "papa de vieja" "papa de viejas" all of them referring as "old woman potato". In addition, names such as "charcheres", "Cualla", "Juarrios", "Cuarrio", "Papa de Monte", "Papa Monte" are mentioned and only one farmer do not know about these wild potatoes. In Chimborazo, the most repeated names are "aya papa" (24\%), "urco papa" (10\%), "tzímbalo" (8\%) besides other names such as "Iobo, chahuara, chavela, papa chavela bejuca, chuco, papa de monte, papa del inca or sacha papa". In Loja, the most common name is "sacha papa" (10\%) and "papa de monte" (6\%), followed by "papa de chacra", although the last one is cultivated (it grows as a weed in corn) it is considered wild by 2 farmers. Other mentioned names are: "papa de monte", "papa chia", "papa chiwa", "papa de cerro", "papa de venado", "papa del genti", 
"tzimbailo", "tzímbalo" and "ojo de venado" some of them referring to hill or mountain potatoes located far from farming lands.

\section{About whether farmers have seen wild potatoes near the fields where they grow their potato landraces}

In figure 1D, it is observed that most of the farmers in the provinces of Carchi, Chimborazo and Loja have not seen wild potatoes near their land (51, 80 and $72 \%$ respectively); on the other hand, 27, 14 and 26\% claimed they have seen those wild potatoes close. Other answers from 22, 6 and 2\% (Carchi, Chimborazo and Loja respectively) include: A farmer in Carchimentioned that he has seen wild potatoes, but away from his crops "he has seen them in the mountains". In Chimborazo, four male farmers mention that in ancient times the elderly knew "sacha papas" or wild potatoes, which inhabited the mountains, but nowadays they have not seen them anymore. Others mention seeing wild potatoes in the mountains and streams, but far away from their crops. In Loja, 5 women and 4 men mentioned that these potatoes used to grow far from their cultivation places and refer to them as "in the mountains", "on the hill", "on the slopes" and "the ravines" but they have not seen them anymore. A woman farmer mentioned that wild potatoes still exist, but she mistakes it for the "papa de chagra" landrace that grows among the corn field.

\section{About whether farmers think that wild potatoes can be crossed with cultivated potatoes.}

As can be seen in figure $1 \mathrm{E}$, only 14,6 and $20 \%$ of the farmers believe that wild potatoes could be crossed with potato landraces in Carchi, Chimborazo and Loja respectively; however, the majority (45, 70 and $46 \%$ respectively) think that these groups of potatoes cannot be crossed. While $41 \%$ of farmers in Carchi, $24 \%$ in Chimborazo and 34\% in Loja mention that they "do not know" if these potatoes would cross.

In Carchi, 2 men and 4 women farmers believe that these potatoes could only be crossed if the crossing would be made artificially in a "laboratory" on purpose; even a male farmer heard that the researchers do so. One farmer mentioned that these groups of potatoes do not interbreed "because they are not alike at all" while another say that they could interbreed because they are "related". In Chimborazo, 3 men and a woman although stated "they do not know", mentioned that "the crossing might be possible", even one farmer said that he would "try" to see if it works. In Loja, a farmer is incredulous that cultivated and wild potatoes can be crossed; another farmer opens the possibility that those potatoes could be crossed and only one farmer affirmed "if they are pollinated, they can be crossed."

\section{About whether farmers know about the uses of wild potatoes.}

In a low percentage 12, 22 and $28 \%$ of farmers in Carchi, Chimborazo and Loja know of some use for wild potato species (Figure $1 \mathrm{~F}$.), while 38,32 and $28 \%$ answered that wild species have no use. Most of the farmers in the 3 micro-centers studied say they do not know if wild species have any use.

In Carchi several uses for wild potato relatives are reported. A farmer mentions the use of wild species as food "they are eaten as snack". Other farmers ( 3 men and 1 woman) mentioned the medicinal properties of wild potatoes: one says that they are crushed with liqueur to be used against "el mal aire" (vomit and 
diarrhea caused by mystic or climatic conditions); another farmer mentioned medicinal use against "espasmo" (headache and chills that are caused by drastic temperature changes). Another farmer mentioned that these wild potatoes are known to form tiny "tubers", which grounded in water are used as a remedy for hair growth. Finally, another farmer mentioned: "mashed wild potatoes were rubbed on horses' geldings to cure them." In Chimborazo, 4 women and 4 men report various uses as food or medicine e.g. "fruits (tzímbalo or chuco) from a wild potato with a purple flower can be eaten. Another mentioned that "ayapapa" (potato wild relative with blue flowers) is used against dandruff. Two women and a man recognized that the "urco papa" is used to cure back pain with the leaves that are picked, crushed, heated and tied back. One farmer mentioned that the fruits of wild potatoes are used to heal frightened children, and another mentioned the use of wild potatoes as ornamental. In Loja, two women and 4 men mentioned that wild potatoes are eaten, referring to the "tzimbailos" fruits, however, it was done in the past. On the other hand, another farmer indicated that wild potatoes (tubers) are not eaten because they are too hard. As medicine, three male farmers mentioned that the "sacha papa" is used to cure "el mal", "el viento", mumps or kidneys.

\section{About exchanging potatoes as a source of potato genetic variability}

In Carchi $54 \%$ of the interviewed farmers exchange potato tubers and the rest (46\%) do not exchange them. In Chimborazo 21\% exchange potatoes while 79\% do not. In Loja, 62\% exchange native potatoes and $38 \%$ do not.

\section{About flowering of potato landraces}

The different potato landraces have a large variation in terms of days to flowering as follows: in Carchi a minimum of 83 days and a maximum of 125 days and a Coefficient of Variation (CV) 14.85\%. For Chimborazo a minimum of 83 days, a maximum of 125 and a CV of $13.38 \%$, while in Loja the minimum is 83 days, a maximum of 133 days and a CV of $16.51 \%$.

\section{Location of native potatoes and their wild relatives in the studied areas}

Figures 2, 3 and 4 present maps with the location of potato landraces and wild relatives collected in each of the micro-centers of diversity: Carchi, Chimborazo and Loja respectively. Each map is accompanied with histograms about the relationship between the number of accessions of potato landraces and wild species regarding altitude (meters above sea level, m.a.s.I.) of collection.

In the province of Carchi at the North of Ecuador (Figure $2 \mathrm{~A}$ ) it is observed that most of the collection records of wild potato relatives are geographically distant from the places where potato landraces are planted. These two groups coincide in the Tulcán canton, but their geographic location is not overlapping. According to figure $2 \mathrm{~B}$, the altitudes where wild potatoes are grown are different from where potato landraces are grown, only at altitudes between 2900 and 3100 m.a.s.l. cultivated and wild coexist, but are far apart. In this province, wild materials of Solanum andreanum and Solanum colombianum have been collected and among the cultivated materials there are diploid (33\%), triploid (4\%) and tetraploid (63\%) of 
S. tuberosum. In the province of Chimborazo in central Ecuador (Figure $3 \mathrm{~A}$ ) we can observe that the collection records of cultivated landraces and wild relatives coincide in the cantons of Guano, Riobamba, Colta and Guamote. According to figure $3 \mathrm{~B}$ there are 3 ranges of altitudes where wild potatoes are grown and overlap with native potatoes grown 2761-3900 m.a.s.l.; however, the two collected materials are geographically distant. In this province, wild materials of Solanum albicans and Solanum colombianum have been collected and of the cultivated materials there are S. tuberosum diploid (8\%), triploid (8\%) and tetraploid (83\%). In the province of Loja in the South of Ecuador (Figure $3 \mathrm{~A}$ ) it is seen that some records of wild and potato landraces coincide in the cantons of Saraguro, Loja and Catamayo. According to figure $3 \mathrm{~B}$, the altitudes where potato landraces and wild relatives are grown overlap in 2 altitudinal ranges 2101-2500 m.a.s.l. and 2501-2900 m.a.s.l., however, similarly to the other microcenters the collection sites are geographically distant. In this province, wild materials of Solanum albornozii and Solanum olmosense have been collected and of the cultivated materials there are $S$. tuberosum diploid $(21 \%)$, triploid (3\%) and tetraploid (76\%).

\section{Discussion}

\section{About the potential hybridization of potato landraces}

Potato landraces naturally produce fruits (berries) in the field, but most farmers report that fruits fall off and rot, or they are collected and consumed as food, which would indicate that eventual dropping of fruits and seed germination at the site is very difficult. Additionally, it is known that self-pollination is common in potatoes and cross-pollination is very rare, especially in tetraploids that correspond to the majority of cultivated species in Ecuador (Cuesta et al., 2002; Monteros-Altamirano et al., 2017). Additionally, mature TPS have a primary-dormancy period lasting 6 to 18 months after berry extraction (D'Antonio and McHale, 1988; Pallais et al., 1989; Pallais et al., 1991; Pallais, 1995; Stuik and Wiersema, 1999), which would make it difficult for the seeds that fall from the fruits and germinate under natural conditions. Anyway, if hybridization would occur, seeds wouldn't be able to survive a process of soil preparation and rotation with other crops, which is common in the study areas according to MonterosAltamirano (2018). Similarly, farmers mainly planting landraces separated in rows produce a physical barrier that prevents outcrossing.

Another result of this study shows that potato landraces present a variety of flowering stages, which would make an eventual pollen flow and potential natural hybridization between them unlikely. However, it is important to consider that in this study the influence of insects as pollinators was not evaluated as reported by Johns (1986) who identifies insects of the genus Bombus sp. and Anthophora sp. as pollinators of native potatoes and wild species in Bolivia.

Probably the existing genetic variability in Ecuador has been accumulated since the historical movement of potato landraces by American ancestors from the center of origin in Peru and Bolivia (Johns and Keen, 1986) and the continuum knowledge and seed sharing of potato landraces by local farmers for centuries (Monteros-Altamirano et al. (2017). Additionally, it is possible that an apparent conscious and 
unconscious selection of potato landraces by farmers occurs similarly to Peru and Bolivia (Johns and Keen, 1986; Jarvis and Hodgkin, 1999), since in Ecuador there is an ongoing process of adaptation of potato landraces to particular ecological Andean conditions. Based on our study, there is no evidence of deliberated hybridization among potato landraces unlike Peru where few specific cases of sexual seed management by farmers have been documented for breeding purposes to eliminate diseases, rejuvenate varieties or create new ones (Quiros et al., 1992). Only in Carchi-Ecuador potato hybridization by an outstanding farmer-researcher in the past, produced a new potato variety, however, nowadays there is no indication that farmers have generated new varieties by using this method.

\section{About wild potato species}

Based on herbarium identification the only "potato-like species" found close to the cultivated potatoes was Solanum caripense Humb. \& Bonpl. ex Dunal which, although looking very similar to wild potato species, belongs to the related section Basarthrum and not to section Petota. This species is a diploid ( $2 n$ $=2 x=24$ ), climbing non-tuberizing herb, and sterile when crossed with potato (Nakitandwe et al., 2007). The wild potatoes reported for Ecuador are far away from the potato fields, in the "monte", a term referring to mountain slopes at the outer limit of the agricultural landscape. This makes crosses between cultivated and wild species not likely to occur.

Most of the farmers growing potato landraces at the studied microcenters do recognize wild potatoes, this is how 31 common names of potato wild relatives were mentioned, these names included both Spanish and Kichwa. Hawkes (1947) registered only three common names of wild potatoes for Ecuador (Aya papa, Papa chio and Sacha papa). It is interesting that in Chimborazo and Loja the "papa del Inca" "papa chia or papa chiwa" is identified as wild, although this could be classified as a "weed species" since this potato coexists in corn fields. In Peru this specific landrace is called "Araq papa" and has been identified as $S$. tuberosum sbsp. andigena, although it is also considered a weed in corn cultivation (De Haan, 2009). The uses identified by farmers for wild species also determine ancestral knowledge, however, their use is less and less frequent since these species are not geographically accessible.

\section{Relationship between cultivated and wild species}

Potato landraces collection points do not coincide with their wild relatives neither in geographic space nor in altitude in the 3 micro-centers studied, which support farmers' observations about the existence of wild potato relatives in places far from their potato crops. In Kenya, a center of diversity for Sorghum sp., Mutegi et al. (2010), found wild relatives in sorghum crops, vacant land, but also many species growing far away from agricultural land; in Ecuador, center of diversity of potatoes, potato landraces and their wild relatives do not match in the vicinity. In Ecuador, altitudinal variation can mean drastic changes in climatic conditions and soil types.

Hypothetically, if a greater sampling were to determine a closeness between the two groups, the species would still have to overcome another limitation, which is that TPS of cultivated and wild potatoes present thermo-dormancy (Monteros, 2002; Cunguán, 2020); which would make it very difficult that, in a very 
eventual crossing with the consequent fall of berries in the field, they germinate and produce seedlings. Additionally, wild and cultivated potatoes have different ploidies and EBN (Endosperm Balance Numbers) that should be sorted out for a potential cross among them. The wild species present in the study areas have the following ploidies and EBN: Solanum albicans (Ochoa) Ochoa, 6x (4EBN); Solanum albornozii Correll, 2x (2EBN); Solanum andreanum Baker, 2x (2EBN); Solanum colombianum Dunal, 4x (2EBN); and Solanum olmosense Ochoa, $2 x(2 E B N)$; and, the cultivated species Solanum tuberosum Andigenum group 2x (2EBN), 3x, 4x (4EBN) (Spooner et al., 2004; Spooner et al., 2014).

Information from farmers and eco-geographic data from this study did not demonstrate a potential cross between wild and cultivated species, Johns and Keen (1986) and Jarvis and Hodkin (1999) indicate that in the center of origin of the potato (around Lake Titicaca), cultivated potatoes and wild species coexist once the later are rarely removed by farmers from growing areas, then promoting hybridization. This type of behavior has determined the origin of diploid and tetraploid cultivated species by gene flow from wild species or weeds (Ugent, 1970). However, this process would be primarily natural and non-farmer-driven process.

Although the results of this study do not demonstrate a potential gene flow between local landraces and / or wild relatives, however, intercropping (Thurston, 1990; Garret et al., 2001) and intermixing of potatoes (Andrivon et al., 2003; Pilet et al., 2006; Finckh et al., 2008) traditionally used by farmers, are indeed effective for other purposes such as controlling the main disease of the crop: Phytophthora infestans, considering that Ecuadorian native potatoes are mostly susceptible to this disease (Monteros-Altamirano, 2011; Monteros-Altamirano and Delgado, 2021).

\section{Genetic erosion of native potatoes and wild species}

When evaluating the presence of microsatellite alleles in native potato cultivars, in Peru, no erosion was detected based on a comparison of alleles found in the field with alleles found in a central potato collection conserved at CIP (De Haan, 2009); similarly in Ecuador Monteros-Altamirano et al. (2017), determine that high genetic diversity is still maintained in situ in the same locations as this study, however, in this case, a decrease in the frequency of farmers who maintain native potatoes in the fields has been already observed in Ecuador, especially in the province of Carchi (Cañizares and Forbes, 1995; Frolich et al., 1999; Cuesta et al., 2005; Monteros-Altamirano, 2018). Additionally, local potato landraces in Ecuador are under threat due to the introduction and use of new high-yielding varieties, high pressure of pests and diseases, and the lack of market opportunities (Cuesta et al., 2005). Similarly, in relation to the wild potato relatives, Naranjo et al. (2020) using the IUCN Red List categories preliminarily categorized the wild potatoes collected as follow: Endangered (Solanum albicans (Ochoa) Ochoa, Solanum albornozii Correll, Solanum chilliasense Ochoa, Solanum chomatophilum Bitter y Solanum olmosense Ochoa); Vulnerable (Solanum andreanum Baker y Solanum minutifoliolum Correll); and, Near Threatened (Solanum colombianum Dunal).

\section{Strategy for the conservation of cultivated and wild native potatoes in Ecuador.}


To maintain the diversity of cultivated potatoes and their wild relatives in Ecuador, it is necessary to implement conservation strategies in situ (on farm) and ex situ. The importance of the complementarity of both systems has already been highlighted by authors such as Engels and Visser (2003) or Jarvis et al. (2000), although these two conservation methodologies have inherent advantages and disadvantages (Altieri, 1987; Brush, 1991; Cohen, 1991; Dulloo, 2010). Currently, thousands of local varieties and wild relatives of the potato are conserved in gene banks (Bamberg et al., 1996; Pavek and Corsini, 2001; CIP, 2020; Monteros-Altamirano et al., 2018). In Ecuador, the National Agricultural Research Institute (INIAP) currently conserve the potato landrace genetic diversity by using mainly in vitro techniques, while the potato wild relatives are conserved mainly as sexual seeds in cold storage (Monteros- Altamirano et al., 2018; Naranjo et al., 2020). At the global level only a small part of the total variability has been used for potato breeding e.g. for adaptation and resistance traits, despite the various technologies available for assessment (Pavek and Corsini, 2001; Hajjar and Hodgkin, 2007).

\section{Declarations}

\section{Acknowledgement}

Authors greatly acknowledged the cooperation extended by Carlos Sevillano and Geovani Suquillo in Carchi, Paola Pilco in Chimborazo, Patricio Ordoñez in Loja during the interviews and data collection. Authors also thankful to native potato farmers in the provinces of Carchi, Chimborazo and Loja for their kindness and willingness in sharing knowledge on their local potatoes. Finally, to Dr. Naga Raju Maddela for the revision of this document.

Funding: The authors received financial support from the National Institute of Agricultural Research (INIAP).

Competing interest: The authors have declared that no competing interests exist.

Availability of data: Any original data related to this publication will be available to the editors under request.

\section{Authors' contributions:}

AMA participated in the conception, coordination and design of the study. AMA, FYJ, JC, LCQ, and KC participated in the interpretation of results and drafting the first manuscript. FYJ, RA and JC were involved in the survey data gathering and maintenance of the field experiments. AMA coordinated funding application. All authors read and approved the final manuscript.

Topic: Genetic resources

\section{References}


Altieri M, Merrick L (1987) In Situ Conservation of Crop Genetic Resources through Maintenance of Traditional Farming Systems. Economic Botany 41 (1): 86-96.

Andrivon D, Lucas JM, Ellissèche D (2003) Development of natural late blight epidemics in pure and mixed plots of potato cultivars with different levels of partial resistance. Plant Pathology 52: 586-594.

Bamberg JB, Longtine CA, Radcliffe EB (1996) Inventory of Tuber-bearing Solanum species. Catalog of Potato Germplasm, Potato Introduction Station, NRSP-6, Sturgeon Bay, WI. USA: 110.

Brush S (1994) Providing farmers' rights through in situ conservation of crop genetic resources. Commission on plant genetic resources. First Extraordinary Session. Rome, 7 - 11 November 1994: 44.

Brush S, Kesseli R, Ortega R, Cisneros P, Zimmerer K, Quiros C (1995) Potato diversity in the Andean Center of Crop Domestication. Conservation Biology 9 (5): 1189-1198.

Brush SB (1991) A farmer-based approach to conserving crop germplasm. Economic Botany 45 (2): 153165.

Brush SB (2007) Farmers' Rights and Protection of Traditional Agricultural Knowledge. World Development 35 (9): 1499-1514.

Brush SB, Carney HJ, Huamán Z (1981) Dynamics of Andean Potato Agriculture. Economic Botany 35 (1): 70-88.

Cañizares G, Forbes G (1995) Foliage resistance to Phytophthora infestans (Mont.) de Bary in the Ecuadorian national collection of Solanum phureja ssp. phureja Juz. \& Buk. Potato Research 38: 3-10.

CIP (2000) CIP in 1999. International Potato Center, Annual Report. Lima, Perú, 34 p.

CIP (2020) International Potato Center. Url: http://www.cipotato.org/potato. (Accessed: 16/11/20).

Cohen J, Williams T, Plucknett D, Shands H (1991) Ex situ conservation of Plant Genetic Resources: global Development and Environmental Concerns. Science 253: 866-872. DOI:

10.1126/science.253.5022.866

Cuesta X, Castillo C, Monteros C (2005) Biodiversidad de las papas nativas ecuatorianas. In: Monteros, C., Jimenez, J.; Cuesta, X. and Lopez, G. (Eds.). Las papas nativas en el Ecuador. Estudios cualitativos sobre oferta y demanda. Capítulo 1. INIAP, PNRT. Papa Andina: 9-10.

Cuesta X, Andrade H, Bastidas O, Quevedo R, Sherwood S (2002) Capítulo 2 Botánica y Mejoramiento Genético. In: Pumisacho M.; Sherwood S. (Eds). El cultivo de la papa en Ecuador. INIAP-CIP. First edition. Pp. 33-42.

Cunguán Haro K, Chalampuente Flores D, Monteros-Altamirano A (2020) Germination and morphometric characteristics of botanical seed of wild potatoes (Solanum spp.). Anais VI Congresso Brasileiro De 
Recursos Genéticos. 9 a 12 novembro de 2020.

http://icongresso.sbrg.itarget.com.br/anais/index/index/cc/3. ISBN 978-65-88187-01-2

D'Antonio VL, McHale NA (1988) Effect of storage temperature and extraction methods on dormancy and germination of true potato seed. American Potato Journal 65, 573-581

https://doi.org/10.1007/BF02908338

De Haan S (2009) Potato diversity at height: Multiple dimensions of farmer-driven in-situ conservation in the Andes. PhD thesis Wageningen University, The Netherlands. 245p.

Dulloo ME, Hunter D, Borelli T (2010) Ex Situ and In Situ Conservation of Agricultural Biodiversity: Major Advances and Research Needs. Not. Bot. Hort. Agrobot. Cluj 38 (2) Special Issue: 123-135.

Engels J, Visser L (2003) A guide to effective management of germplasm collections. IPGRI Handbooks for Genebanks No. 6. IPGRI, Rome, Italy: 165.

ESRI (2011) ArcGIS Desktop: Versión 10. Redlands, CA: Sistemas Ambientales Instituto de Investigación.

FAO (1991) Potato production and consumption in developing countries. Plant Production and Protection. Paper 110. Rome, FA0.29p.

FAO (1998) The State of the World's plant genetic resources for food and agriculture. Food and Agriculture Organization of the United Nations. 29p.

Finckh MR, Wolfe MS, Lammerts van Bueren ET (2007) The Canon of Potato Science: 32. Variety Mixtures and Diversification Strategies. Potato Research 50: 335-339. DOI 10.1007/s11540-008-9081-6

Frolich L, Sherwood S, Hemphill A, Guevara E (1999) "Eco papas": through potato conservation towards agroecology. ILEIA Newsletter: 44-45.

Garrett KA, Nelson RJ, Mundt CC, Chacón G, Jaramillo RE, Forbes GA (2001) The effects of host diversity and other management components on epidemics of potato late blight in the humid highland tropics. Phytopathology 91: 993-1000.

Hajjar R, Hodgkin T (2007) The use of wild relatives in crop improvement: A survey of developments over the last 20 years. Euphytica156:1-13. DOI 10.1007/s10681-007-9363-0

Hawkes J (1947) On the origin and meaning of South American Indian potato names. Journal of Linnean society of London Botany 53 (350): 205-250.

Hawkes $J$ (1988) The evolution of cultivated potatoes and their tuber-bearing wild relatives. Kultupflanze 36: 189-208. https://doi.org/10.1007/BF01986960

Hawkes JG (1990) The potato-evolution, biodiversity and genetic resources. Smithsonian Institution Press, Washington DC: 259. 
Huerta R (1966) Historia del Ecuador. Edición 1966: 25-68. ISBN: 978-90-8585-331-2.

IBM Corp. Released (2011) IBM SPSS Statistics for Windows, Version 20.0. Armonk, NY: IBM Corp. InfoStat (2008) InfoStat versión 2008. Grupo InfoStat, FCA, Universidad Nacional de Córdoba, Argentina. Jarvis DI, Hodgkin T (1999) Wild relatives and crop cultivars: detecting natural introgression and farmer selection of new genetic combinations in agroecosystems. Molecular Ecology 8, S159-S173. https://doi.org/10.1046/j.1365-294X.1999.00799.x

Jarvis DI, Myer L, Klemick H, Guarino L, Smale M, Brown AHD, Sadiki M, Sthapit B, Hodgkin T (2000) A Training Guide for In Situ Conservation On-farm. Version 1. International Plant Genetic Resources Institute, Rome, Italy: 160.

Johns T, Keen SL (1986) Ongoing evolution of the potato on the altiplano of Western Bolivia. Economic Botany, 40, 409-424. https://doi.org/10.1007/BF02859652

Monteros A (2002) Dormancy and germination of true potato (Solanum tuberosum L.) Seeds: characterization of endo- $\beta$-mannanase genes. Thesis MSc. Oregon State University. 67 p.

Monteros-Altamirano A (2011) Potato landraces: description and dynamics in three areas of Ecuador. PhD. Thesis. Wageningen University.160 p. ISBN-978-94-6173-140-1

Monteros-Altamirano A (2018) On-farm conservation of potato landraces in Ecuador. Agronomía Colombiana. 36 (3) 198-200. https://Doi.10.15446/agron.colomb.v36n3.66640

Monteros-Altamirano A, Buitrón-Bustamante J, Orbe-Vergara K, Cuesta-Subía X (2017) Ecuadorian potato landraces: traditional names and genetic identity. Rev. Fitotec. Mex. Vol. 40 (4): 481-489. ISSN 01877380. https://doi.org/10.35196/rfm.2017.4.481-489

Monteros-Altamirano A, Delgado R (2021) Late blight resistance of Ecuadorian potato landraces: field evaluation and farmer's perception. Accepted article in journal: Agrorevista Luz, Facultad Agronomía U.C.V. Venezuela. Volumen 38. Número 3. Año 2021.

Monteros-Altamirano A, Tacán M, Peña G, Tapia C, Paredes N, Lima L (2018) Guía para el manejo y conservación de recursos fitogenéticos en Ecuador. Protocolos. Publicación miscelánea No. 432. INIAPFAO. Estación Experimental Santa Catalina. Departamento Nacional de Recursos Fitogenéticos, Ecuador. 104 p. ISBN: 978-9942-22-262-6

Mutegi E, Sagnard F, Muraya M et al. (2010) Ecogeographical distribution of wild, weedy and cultivated Sorghum bicolor (L.) Moench in Kenya: implications for conservation and crop-to-wild gene flow. Genet Resour Crop Evol 57, 243-253 https://doi.org/10.1007/s10722-009-9466-7 
Nakitandwe J, Trognitz F, Trognitz B (2007) Genetic mapping of Solanum caripense, a wild relative of pepino dulce, tomato and potato, and a genetic resource for resistance to potato late blight. Acta Horticulturae 745: 333-342. DOI:10.17660/ActaHortic.2007.745.19

Pallais N (1995) High temperature and low moisture reduce the storage requirement of freshly harvested true potato seed. J. Amer Soc Hort Sci. 120: 699-702. https://doi.org/10.21273/JASHS.120.4.699

Pallais N, Asmat H, Fong N, Santos-Rojas J (1989) Factors affecting seedling vigor in potatoes: I. Stage of development. American Potato Journal 66: 793-801. https://doi.org/10.1007/BF02853960

Pallais N, Espinola NY, Falcon RM, García (1991) Improving Seedling Vigor in Sexual Seeds of Potato Under High Temperature. HortScience 26(3):296-299. https://doi.org/10.21273/HORTSCI.26.3.296

Pavek JJ, Corsini DL (2001) Utilization of Potato Genetic Resources in Variety Development. Amer J of Potato Res 78: 433-441. https://doi.org/10.1007/BF02896375

Pilet F, Chacón G, Forbes GA, Andrivon D (2006) Protection of Susceptible Potato Cultivars Against Late Blight in Mixtures Increases with Decreasing Disease Pressure. Phytopathology 96 (7): 777-783. https://doi.org/10.1094/PHYTO-96-0777

Quiros C, Brush B, Douches D, Zimmerer K, Huestis G (1990) Biochemical of variability of Andean cultivated potatoes. Economic Botany 44 (2): 254-266. https://doi.org/10.1007/BF02860490

Quiros CF, Ortega R, Van Raamsdonk LWD et al. (1992) Amplification of potato genetic resources in their center of diversity: the role of natural outcrossing and selection by the Andean farmer. Genetic Resources and Crop Evolution, 39, 107-113. https://doi.org/10.1007/BF00051229

Reid A, Hof L, Felix G, Rücker B, Tams S, Milczynska E, Esselink D, Uenk G, Vosman B, Weitz A (2011) Construction of an integrated microsatellite and key morphological characteristic database of potato varieties on the EU Common Catalogue. Euphytica. https://DOI 10.1007/s10681-011-0462-6

Reyes OE (1984) Breve historia general del Ecuador. Tomo I. Duodécima Edición: 415.

Naranjo E, Rosero L, Tapia C, Monteros-Altamirano Á, Tacán M, Lima L, Peña G, Paredes N, Villarroel J (2020) Ecuadorian catalogue of wild species related to sweetpotato, rice, lima bean (butter bean), potato and eggplant. INIAP. National Department of Plant Genetic Resources. Santa Catalina Experimental Station. Miscelaneus publication No. 455. Mejía-Ecuador. INIAP-Global Crop Diversity Trust. 24p. ISBN978-9942-22-426-2.

Spooner D, Castillo R, López L (1992) Ecuador, 1991 potato germplasm collecting expedition: taxonomy and new germplasm resources. Euphytica 60: 159-169. https://doi.org/10.1007/BF00039394

Spooner D, Ghislain M, Simon R, Jansky SH, Gavrilenko T (2014) Systematics, Diversity, Genetics, and Evolution of Wild and Cultivated Potatoes. Bot. Rev. 80(4): 283-383. https://doi.org/10.1007/s12229- 
Spooner D, Nuñez J, Trujillo G, Herrera R, Guzmán F, Ghislain M (2007) Extensive simple sequence repeat genotyping of potato landraces supports a major reevaluation of their gene pool structure and classification. PNAS 104 (49): 19398-19403. https://doi.org/10.1073/pnas.0709796104

Spooner D, van den Berg R, Rodríguez A, Bamberg J, Hijmans R, Lara Cabrera S (2004) Systematic Botany Monographs. Volume 68. The American Society of Plant Taxonomists. 209 p.

Struik P, Wiersema SG (1999) Seed potato technology. Wageningen Pers, Wageningen, The Netherlands. 383p.

Thurston D. 1990. Plant disease Management practices of traditional farmers. Plant Disease 74 (2): $96-$ 101. 10.1094/PD-74-0096

Ugent D (1970) The Potato. What is the botanical origin of this important crop plant, and how did it first become domesticated? Science, 170, 1161-1166.

Upadhya N, Cabello R (2000) Influence of size and density on the performance of direct seedling trnasplants from hybrid true potato seed. IN CIP Program Report 1999-2000. Cip, Lima, Peru. Pp. 207-210.

Vavilov NI (1927) Geographical regularities in the distribution of the genes of cultivated plants. Preliminary Communication. Original: 1927. Bull. Appl. Bot. Genet. Plant-Breed. (Leningrad). 17(3): 411419 (in Russian): 420-428 (in English].

Zeidler J (2008) The Ecuadorian formative. Chapter 24. In: Silverman H., and Isbell W.H. (Eds.). Handbook of South American Archaeology. Springer, New York: 459-483. https://doi.org/10.1007/978-0-387-749075_24

Zimmerer K (1991) The regional biogeography of native potato cultivars in highland Peru. Journal of Biogeography 18: 165-178.

\section{Figures}



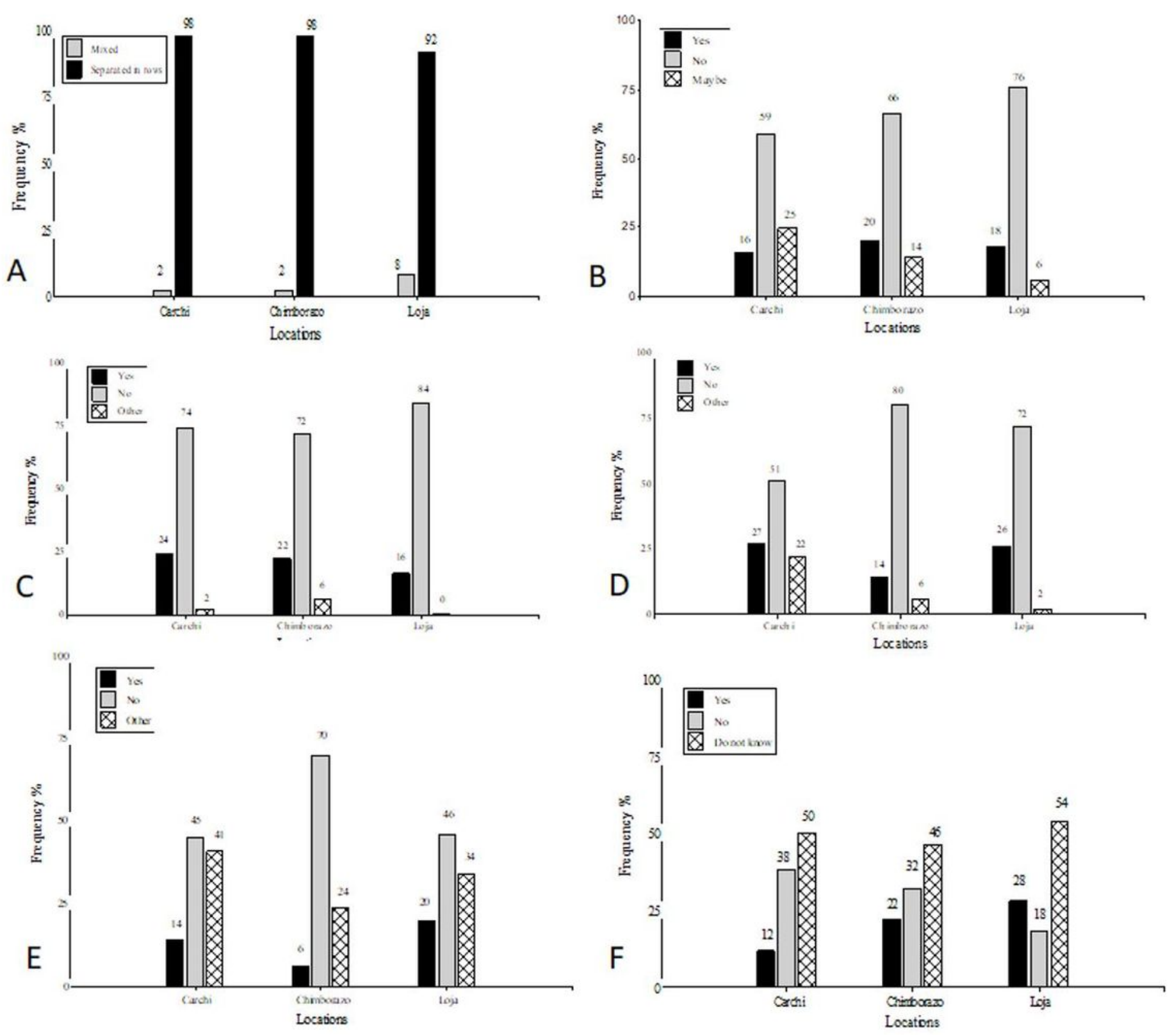

Figure 1

Frequencies for responses of 150 farmers in three micro-centers of diversity in Ecuador (Carchi, Chimborazo and Loja provinces), in relation to their potato landraces and the potential relationship with their wild relatives in the area: A. Do you cultivate the native potato varieties mixed or separated in rows? B. Do you think that if you plant the potatoes together they will cross? C. Do you collect potato fruits in the field? D. Have you seen wild potatoes near the field where you grow your native potatoes? E. Do you think wild potatoes can be crossed with cultivated potatoes? F. Do you know what wild potatoes are used for? 

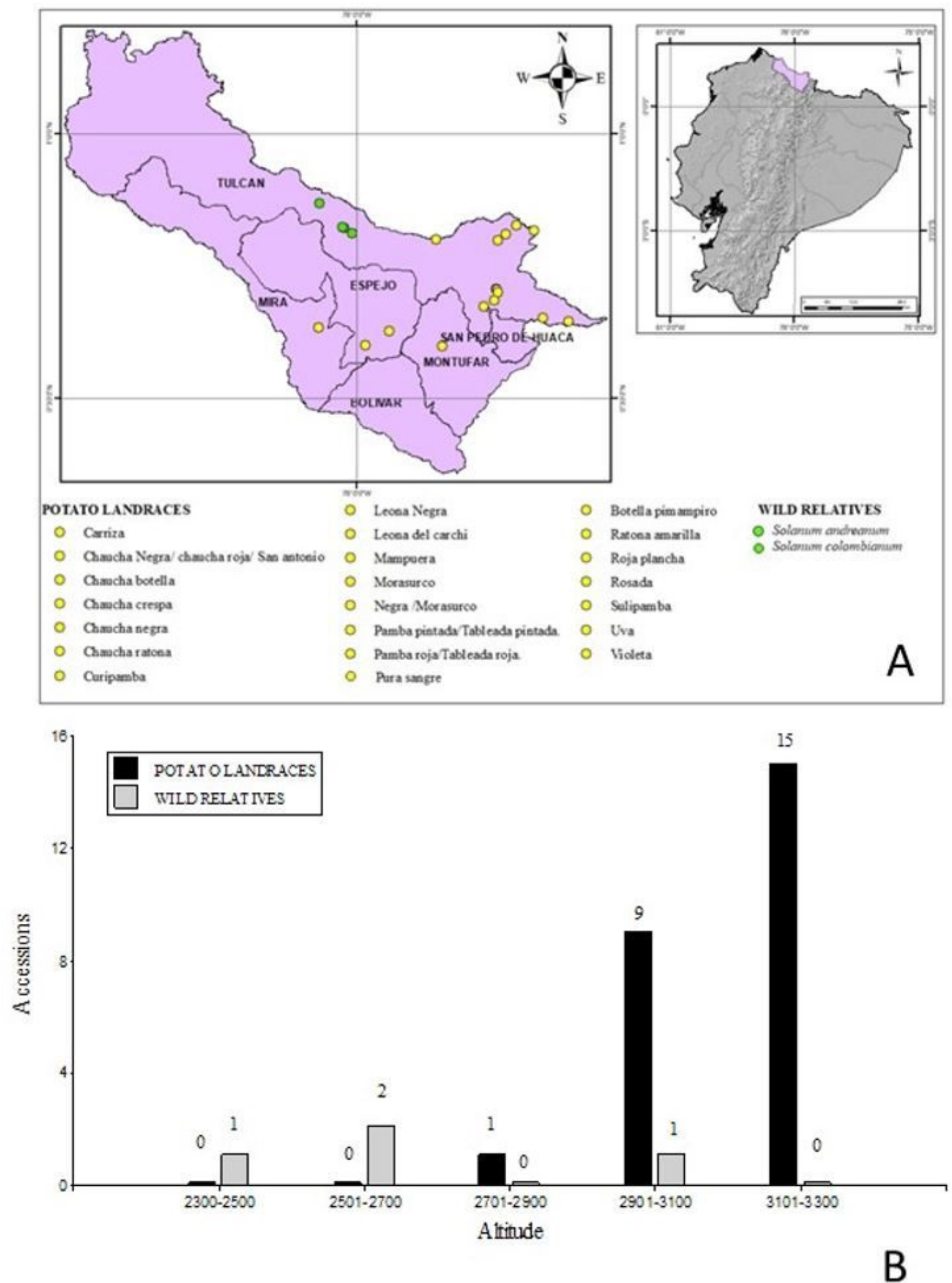

Figure 2

A. Map of the location of potato landraces and wild relatives collected in Ecuador, Carchi microcenter. B. Number of accessions of potato landraces and their wild relatives in relation to the collection altitude (m.a.s.l.) in Carchi-Ecuador. Note: The designations employed and the presentation of the material on this map do not imply the expression of any opinion whatsoever on the part of Research Square concerning 
the legal status of any country, territory, city or area or of its authorities, or concerning the delimitation of its frontiers or boundaries. This map has been provided by the authors.
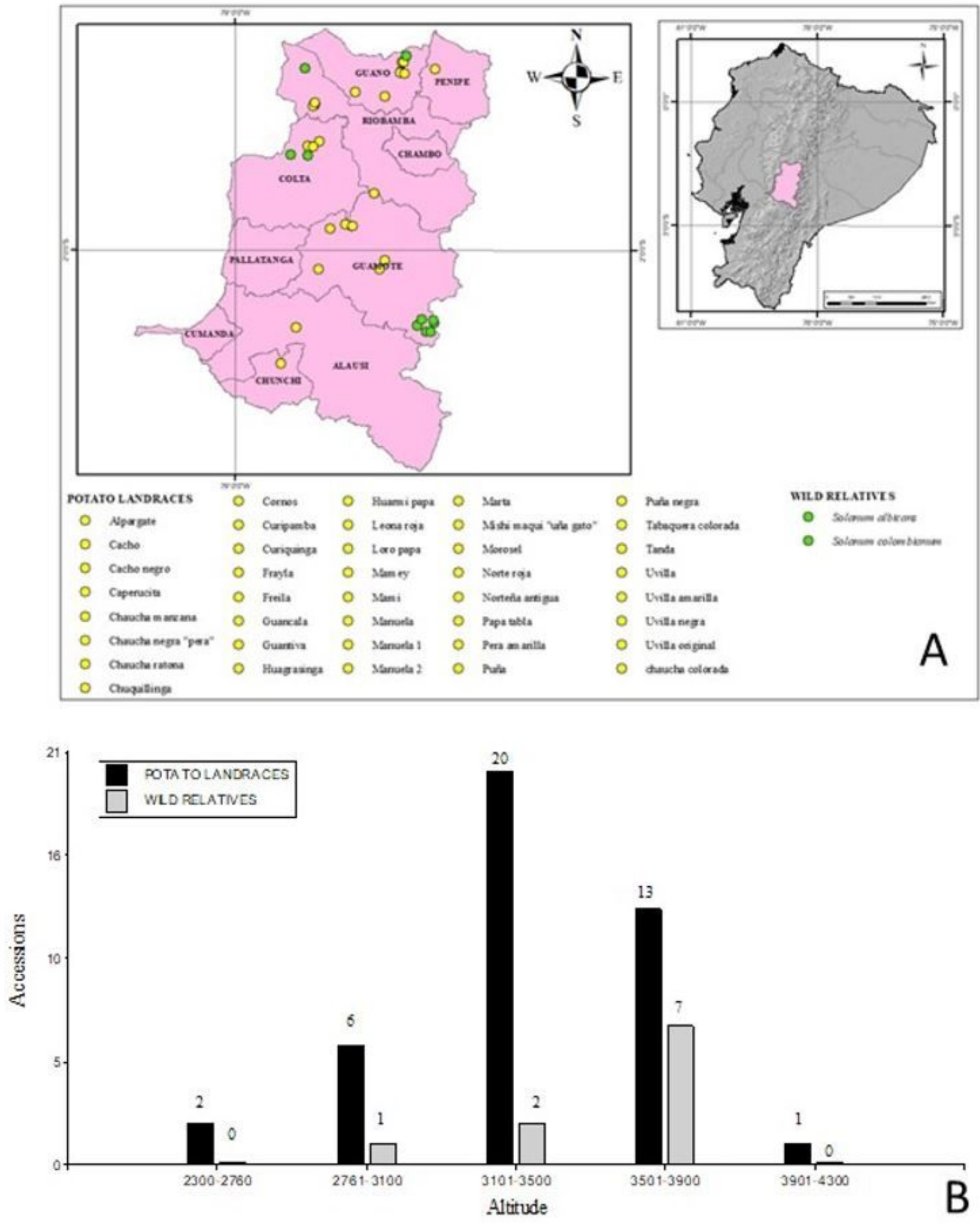

Figure 3

A. Map of the location of collections of cultivated potato landraces and wild relatives in Ecuador, Chimborazo microcenter. B. Number of accessions of potato landraces and their wild relatives in relation to the collection altitude (m.a.s.I.) in Chimborazo-Ecuador. Note: The designations employed and the 
presentation of the material on this map do not imply the expression of any opinion whatsoever on the part of Research Square concerning the legal status of any country, territory, city or area or of its authorities, or concerning the delimitation of its frontiers or boundaries. This map has been provided by the authors.
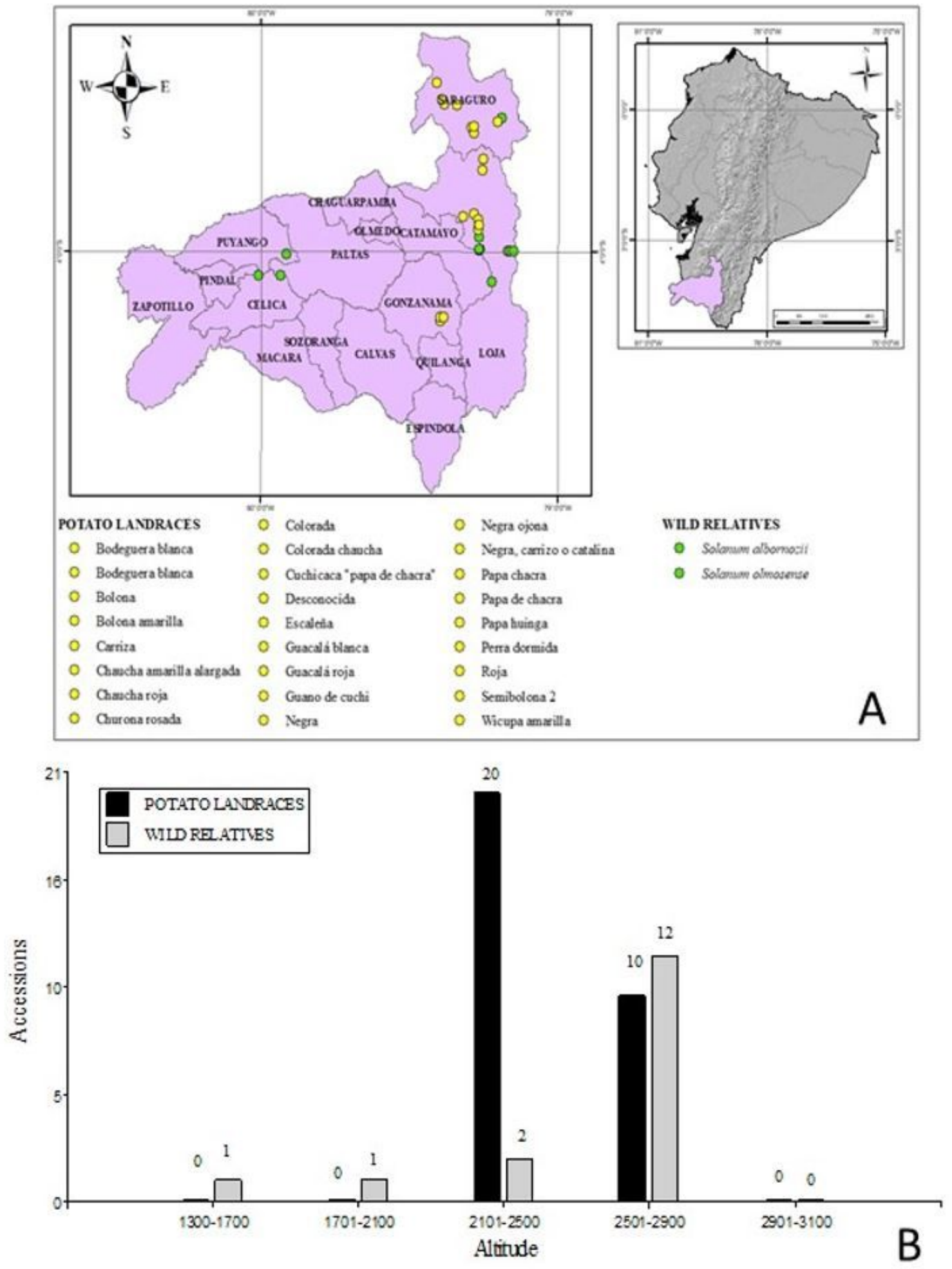

Figure 4 
A. Map of the location of collections of cultivated potato landraces and wild relatives in Ecuador, Loja microcenter. B. Number of accessions of potato landraces and their wild relatives in relation to the collection altitude (m.a.s.I.) in Loja-Ecuador. Note: The designations employed and the presentation of the material on this map do not imply the expression of any opinion whatsoever on the part of Research Square concerning the legal status of any country, territory, city or area or of its authorities, or concerning the delimitation of its frontiers or boundaries. This map has been provided by the authors. 